FILOZOFIA

Roč. 75,2020 , č. 7

DOI: https://doi.org/10.31577/filozofia.2020.75.7.3

\title{
K NEGATÍVNEMU NAZERANIU M. ROTHBARDA NA MYŠLIENKU PRÁV ZVIERAT
}

MARTIN TURČAN, Právnická fakulta Univerzity Komenského v Bratislave, Katedra teórie práva a sociálnych vied, Bratislava, SR

TURČAN, M.: On the Negative View of M. Rothbard on the Idea of Animal Rights

FILOZOFIA, 75, 2020, No 7, pp. $539-554$

The article deals with the approach of the right-wing libertarian, anarcho-capitalist, Murray Rothbard to the issue of animal rights. The author offers a critical analysis of his dismissal statements in the work Ethics of Liberty. He deals with Rothbard's arguments and confronts them with the arguments of Peter Singer and Gary Francione. The author pays special attention to Rothbard's argument from the nature of animal warfare, which is one of the reasons for Rothbard's view on animal rights. Based on a hypothetical example of beings from another world, which Rothbard himself mentions, the author refutes his argument and points to the problem of inconsistency in Rothbard's thinking. Given that this argument is not (and cannot be) a central argument for Rothbard, the author then focuses on Rothbard's central argument from the very notion of the concept of a right. The difference between Rothbard and Francione is, in this respect, conceptual (each of them works with a different understanding of the concept of a right). The difference between Rothbard and Singer is basically paradigmatic. In this context, the author points out that both anarcho-capitalism and utilitarianism are reductionist theories and considers the need to find a non-reductionist solution. However, in the controversy, he leans to the side of Singer, due to the moral inadmissibility of Rothbard's assumption of the priority of individual freedom over relevance of any moral good or evil (under the respect of persons but not of other sentient beings), which cannot be understood other than Rothbard's ethical thesis.

Keywords: Rothbard - Libertarianism - Animal rights - Singer - Francione - Ethics

0. Úvod

Murray N. Rothbard (1926 - 1995), významný americký ekonóm a politický myslitel' dvadsiateho storočia, je hlavným predstavitel’om krajného krídla pravicového libertarianizmu zvaného anarchokapitalizmus. Ako radikálny zástanca individuálnej slobody Rothbard vo svojich spisoch presadzuje myšlienku zrušenia štátu a zavedenia absolútne slobodnej spoločnosti. Nazdáva sa, že jednoduché rešpektovanie majetkových práv zabezpečí funkčné spolužitie všetkých. Hovorí o princípe neagresie, ktorý sa 
v pravicovom libertariánskom myslení nerozlučne spája s konceptom negatívnych práv. Rothbard i d’alší pravicoví libertariáni uznávajú výlučne negatívne práva (práva „od niečoho“), neuznávajú teda pozitívne práva (práva „na niečo“). Pre Rothbarda to znamená, že nikto si nemôže nárokovat' pomoc druhého, že každý sa smie domáhat' len nezasahovania do svojej vlastnej sféry.

Teória, ktorú Rothbard prináša a ktorú dnes jeho nasledovníci húževnato obhajujú, nie je individuálno-etickou teóriou, ale sociálno-etickou (nejde o etiku jednotlivca, ale o etiku spoločenstva). Zakladá sa na myšlienkach Johna Locka, najmä na jeho chápaní súkromného vlastníctva a prirodzeného zákona. Rothbard sa snaží dotiahnut' tieto myšlienky do krajných dôsledkov. V rámci svojej koncepcie prirodzených práv, samozrejme, sústred'uje svoju pozornost' na človeka, avšak vo svojom klúčovom diele Etika slobody nechce nechat' nezodpovedanú ani otázku práv zvierat. ${ }^{1}$ Venuje jej tu jednu útlu kapitolu, v ktorej sa voči takejto idei vyjadruje odmietavo.

Predmetom tohto príspevku bude kritická analýza danej kapitoly. Poukážem na problematickost' niektorých Rothbardových vyjadrení, vykonám komparáciu jeho pozície s pozíciou Petra Singera (ktorá je bezpochyby najvýraznejšou etickou koncepciou v prospech ochrany zvierat $\mathrm{v}$ súčasnosti), ako aj stručnú komparáciu s pozíciou Garyho Francioneho (v danom ohl'ade zrejme najradikálnejšieho abolicionistu súčasnosti), a na hypotetickom príklade bytostí z iného sveta i na základe pojmu práv ako takého rozvediem niektoré argumenty $\mathrm{v}$ prospech či neprospech týchto prístupov. Vlastné hodnotenie uvediem $\mathrm{v}$ závere.

\section{Rothbardovo chápanie práv zvierat}

Svoje stručné pojednanie o spomínanej téme Rothbard začína konštatovaním, že v ostatnom čase je čoraz väčšou módou rozširovat' koncept práv z l'udských bytostí na zvieratá, čo má za následok objavujúce sa tvrdenia o údajnej neprípustnosti zabíjania a konzumácie zvierat (Rothbard 2009, 204). Prvé vydanie Etiky slobody pochádza z roku 1982, čo znamená, že Rothbardov výrok je starý takmer štyridsat’ rokov. V západnom svete odvtedy nezanedbatel'ne vzrástol vplyv etických dôrazov profesora Petra Singera, najznámejšieho vegána a utilitaristu súčasnosti, a čiastočne i vplyv deontologicky orientovaných zástancov myšlienky práv zvierat, akým bol najmä nedávno zosnulý filozof Tom Regan (1938 - 2017) a ako je aktuálne najmä profesor práva Gary Francione. Menovaní, na ktorých tu zrejme Rothbard naráža, v tom čase so svojimi hnutiami v podstate ešte len začínali. Ich argumentácia však ostala $\mathrm{v}$ priebehu času $\mathrm{v}$ jadre rovnaká

\footnotetext{
${ }^{1} \mathrm{Na}$ účely tohto príspevku nepovažujem za potrebné zaoberat' sa definíciou pojmu zviera, aj ked', ako ukazuje napríklad Jemelka (2013, 483 - 484), táto môže byt' pomerne problematická.
} 
a dnes sa k nej vytrvalo hlásia ich prívrženci. ${ }^{2}$ Rothbard v rámci svojej libertariánskej koncepcie takéto prístupy odmieta a ideu práv zvierat pomerne ostro kritizuje. Robí to $\mathrm{z}$ troch dôvodov:

Prvým, menej dôležitým dôvodom je tvrdenie, že v prípade uznania práv zvierat narazíme na problém, kam položit' hranicu určujúcu, ktoré živé organizmy týmito právami disponujú a ktoré nie. Tento svoj argument je Rothbard ochotný doviest' $a d a b$ surdum: „Nie je napríklad mnoho teoretikov, ktorí by šli tak d’aleko ako Albert Schweitzer a popierali právo kohokol'vek šliapnut' na švába. Pokial' by bola táto teória d’alej rozšírená zo seba si vedomých živých bytostí na všetky živé bytosti, ako sú baktérie alebo rastliny, l'udské pokolenie by pomerne rýchlo zaniklo“ $(2009,204){ }^{3}$

Druhým, tým zásadnejším dôvodom pre odmietnutie myšlienky práv zvierat je pre Rothbarda neaplikovatel'nost' pojmu práv na zvieratá. Pojem práv totiž podla neho predpokladá schopnosti, ktoré má len človek. Rothbard zdôrazňuje, že otázka práv nie je emocionálna záležitost', ale záležitost' rozumu, a že l'udské práva sú ukotvené v povahe človeka charakteristickej znakmi, ako sú „l’udská schopnost' vedomej vol'by, nutnost' používat' rozum a úsilie o osvojenie ciel'ov a hodnôt, aby sa človek dozvedel o svete, aby usiloval o svoje ciele za účelom prežitia a prosperity, schopnost' a potreba komunikovat' a pôsobit' na iné l'udské bytosti a zúčastňovat' sa del'by práce. Stručne povedané, človek je racionálny a spoločenský tvor. Žiadnym iným zvieratám alebo bytostiam nie je daná táto schopnost' logicky uvažovat', činit' vedomé vol'by, pretvárat' svoje prostredie za účelom prosperity alebo vedome spolupracovat' $v$ spoločnosti v rámci del'by práce“ (2009, 204).

Prirodzené právo sa teda podl'a Rothbarda nutne viaže k živočíšnemu druhu. ${ }^{4} \mathrm{Je}$ síce ateista, no v danom kontexte odkazuje aj na Bibliu a uvádza, že „,[b]iblický príbeh nám umožnil pochopit', že človeku bola ,daná‘ nadvláda, alebo by sme mohli povedat', že v rámci prirodzeného práva ,má " nadvládu nad všetkými živočíšnymi druhmi na zemi““ (2009, 205). Teologické zdôvodnenie nadradenosti človeka nad zvieratami, samozrejme, nie je pre Rothbarda podstatné, domnieva sa však, že svojím spôsobom vystihuje jeho dôraz.

\footnotetext{
${ }^{2}$ Od konzekvencialistu Singera sa Regan a Francione líšia tým, že vychádzajú z deontológie. Singer v priebehu času vykonal drobnú korekciu svojej koncepcie opustením preferenčného utilitarizmu a príklonom ku klasickému (hedonistickému) utilitarizmu. Regan a Francione sa neskôr rozdelili $\mathrm{v}$ dôrazoch aj ideách. Zatial' čo Regan sa stal umiernenejším, Francione odmietol akúkol'vek podporu „zmierňovacích reforiem“ ako nespravodlivých a požaduje okamžitý absolútny zákaz využívania zvierat l'ud'mi. Rozdiely medzi Reganom a Francionem sú aj filozofické (Regan napríklad pripúšt’al uprednostnenie záchrany l'udského života pred zvieracím; Francione v zásade pokladá oba životy za rovnocenné).

${ }^{3} \mathrm{~V}$ záujme jazykovej jednoty citujem $\mathrm{v}$ tomto príspevku všetky pôvodne české zdroje vo vlastnom preklade do slovenského jazyka.

${ }^{4}$ Explicitne to uvádza $(2009,205)$.
} 
Rothbard napokon používa tretí argument, ktorým je poukázanie na prirodzenost' živočíšneho boja: „To, že koncept etiky živočíšnych druhov je súčast'ou povahy sveta, môžeme navyše vidiet' pri pozorovaní činností ostatných živočíšnych druhov v prírode. Je viac než len žartom, ak poukážeme na to, že zvieratá koniec-koncov nerešpektujú ,práva“ iných zvierat. Taká je povaha sveta a všetkých prírodných druhov, že žijú vd’aka pojedaniu ostatných druhov. Prežitie medzi druhmi je vecou zubov a pazúrov. Bolo by istotne absurdné tvrdit', že vlk je ,zlý‘, pretože žije vd'aka tomu, že požiera a ,dopúšt’a sa agresie ' voči jahňatám, kurčatám atd'. Vlk nie je zlá bytost', ktorá sa ,dopúšt’a agresie 'voči ostatným druhom; jednoducho len nasleduje prirodzený zákon svojho vlastného prežitia. Tak isto koná i človek. Je rovnako absurdné tvrdit', že človek sa ,dopúšt’a agresie 'voči kravám a vlkom, ako je absurdné tvrdit', že vlk sa ,dopúšsta agresie ' voči ovciam. Okrem toho, ak zaútočí vlk na človeka a človek ho zabije, bolo by absurdné tvrdit', že vlk je ,zlým agresorom‘, alebo že bol ,potrestaný‘ za svoj ,zločin'. Avšak práve také by boli dôsledky rozširovania etiky prirodzených práv na zvieratá. Akýkol'vek koncept práv, zločinnosti alebo agresie sa môže vzt'ahovat' len na konanie človeka alebo skupiny l'udí voči iným l'udským bytostiam" (2009, 205).

$\mathrm{V}$ rámci úvah o rozdieloch medzi l'ud'mi a zvieratami a v súvislosti s témou živočíšneho boja, sa Rothbard v Etike slobody stručne dostáva aj k otázke práv pomyselných „Mart’anov“. Uvádza, že keby sa objavili bytosti, ktoré by mali vlastnosti ako my (schopnost' sebauvedomenia, komunikácie, del'by práce a pod.), tak by tiež mali práva, ktoré momentálne prislúchajú len l'ud’om. Keby však títo „Mart’ania“ mali povahu upírov, ktorí by žili z našej krvi, tak by boli „bez ohl'adu na svoju inteligenciu našimi úhlavnými nepriatel'mi a my by sme nemohli uvažovat' o tom, že majú nárok na l'udské práva. Úhlavnými nepriatel'mi nie preto, že by boli hriešnymi agresormi, ale vzhl'adom na ich potreby a požiadavky plynúce $\mathrm{z}$ ich prirodzenosti, ktoré by boli nevyhnutne v rozpore s našimi““ $(2009,205)$. Rothbard teda upiera prirodzené práva prirodzeným nepriatel’om človeka, akokol'vek racionálni a vyspelí by mohli byt'.

Svoju polemiku o právach zvierat napokon ukončuje myšlienkou, že „,[v] notoricky známom vtipe o tom, že ,uznáme práva zvierat, kedykol'vek o ne požiadajú ‘, sa v skutočnosti skrýva drsná pravda. Skutočnost', že zvieratá, samozrejme, nemôžu požiadat' o svoje ,práva', je súčast'ou ich prirodzenosti a čiastočnou príčinou, prečo sú l'udským bytostiam zjavne nerovnocenné a nemajú rovnaké práva. Pokial' by niekto protestoval, že deti takisto nemôžu požiadat' o svoje práva, odpoved'ou by samozrejme bolo, že deti sú budúcimi dospelými l'ud'mi, zatial' čo zvieratá evidentne nie“ $(2009,206)$. 


\section{Krátka komparácia s relevantnými konkurenčnými pohl’admi}

Rothbardovo nazeranie na otázku práv zvierat si žiada konfrontáciu s pohl’admi P. Singera a G. Francioneho, ktorí aktuálne predstavujú dve najvýraznejšie postavy konzekvencialistického a deontologického prístupu $\mathrm{k}$ danej téme.

\subsection{Singerov utilitaristický prístup}

V súvislosti s Rothbardovou otázkou, ako rozlíšit žiaduci status zvierat od žiaduceho statusu iných organizmov (argument č. 1), nemožno opomenút' odpoved', ktorú prináša Peter Singer. Ako utilitarista predkladá jednoduché kritérium, ktorým je schopnost' cítit' bolest' (a potešenie). Tú hmyz, rastliny ani baktérie podl'a aktuálneho vedeckého poznania nemajú. Rothbard však nie je utilitarista ako Singer. Jeho koncepcia nie je konzekvencialistická ako Singerova, ale deontologická. Nevychádza z dôsledkov konania, ale z povinností voči jednotlivcom, a to najmä z požiadavky rešpektu súkromného vlastníctva. V jeho sociálnej etike nejde o maximalizáciu potešenia a minimalizáciu bolesti. Ide o apel na individuálnu slobodu, ktorá je prejavom dôstojnosti človeka, akou zvieratá nedisponujú (hoci treba povedat', že Rothbard v danom diele pojem l'udskej dôstojnosti spomína len raz, aj to v rámci citátu od iného autora; 2009, 66).

Rozdiel medzi Rothbardom a Singerom je teda paradigmatický a súvisí s nastavením základného kritéria, ktorým je u Singera bolest' (a potešenie), zatial' čo u Rothbarda je ním l'udská prirodzenost'. Singer označuje zakotvenie právnej a morálnej ochrany človeka v l’udskej prirodzenosti za svojvol'né, za prejav tzv. druhizmu (angl. speciesism), a prirovnáva ho $\mathrm{k}$ rasizmu či k sexizmu, ktoré tiež aplikujú arbitrárne kritériá (Singer 2008, 46).

Tento prvý dôvod, ktorý tkvie údajne v nejasnej hranici ochrany zvierat, však nie je pre Rothbarda po prípadnom uznaní ich práv t’ažiskový, ako sám uvádza. Ťažiskový je preňho argument, že pojem (subjektívnych) práv predpokladá schopnost' nositela uplatnit' si ich, a tú zvieratá zjavne nemajú.

Vo vzt'ahu k tomuto druhému argumentu Singer podotýka, že on pre svoju koncepciu ochrany zvierat pojem práv vôbec nepotrebuje. Odkazuje na zakladatel'a utilitarizmu Jeremyho Benthama, ktorý síce tiež na jednom mieste explicitne hovorí o právach zvierat, avšak, ako podotýka Singer, ide mu „skôr o rovnost', než o práva samotné“. V inej známej pasáži napríklad Bentham označuje ,prirodzené práva“ ako ,nezmysel' a ,prirodzené nepremlčatel'né práva' ako ,nafúknutý nezmysel‘. Morálne práva $\mathrm{v}$ jeho ponímaní boli akousi skratkou, pod ktorou mal v skutočnosti na mysli ochranu, ktorá by z morálneho hl'adiska mala byt' poskytnutá l'ud'om aj zvieratám. Ťažisko morálnej diskusie teda nespočíva na existencii určitých práv, pretože tie musíme aj tak zdôvodnit' na základe schopnosti trpiet' alebo prežívat' št’astie. Takto môžeme diskutovat' o rovnosti zvierat bez toho, aby sme sa zamotali do filozofickej 
polemiky o povahe práva“ $(2008,45)$. Uvádza, že „,[p]rávnický jazyk je len výhodnou politickou skratkou. V období tridsat'sekundových spravodajských klipov je ešte cennejší, než za čias Benthama. V našej diskusii o radikálnej zmene postojov voči zvieratám ho ale nebudeme potrebovat'. Ak nejaká bytost' trpí, nič nás neoprávňuje k tomu, aby sme odmietli zobrat’ jej utrpenie do úvahy“ (tamtiež).

Singer teda zdôrazňuje, že jeho základným morálnym kritériom je schopnost' cítit' bolest' (a potešenie) a podotýka, že ochrana zvierat si pojem práv v skutočnosti nevyžaduje. Tvrdí vlastne, že je našou morálnou povinnostou niektoré hodnoty chránit' (objektívnym) právom bez ohl'adu na to, či danú ochranu nazveme (subjektívnym) právom (teda oprávnením, právnym nárokom) chráneného alebo nie. ${ }^{5}$ Podobne ako chránime určité druhy rastlín, môžeme, ba máme osobitne chránit' zvieratá. Na rozdiel od rastlín však nie vzhl’adom na hodnotu, ktorú majú pre nás, ale preto, že sú cítiace tvory - čiže s ohl'adom na žiaduci dôsledok nášho konania, ktorým má byt' maximalizácia potešenia a minimalizácia bolesti vo svete. Právna ani morálna ochrana si teda vždy nutne nevyžadujú pojem subjektívneho práva (ani o chránených stromoch predsa nehovoríme, že majú ,právo na život“).

Na Singerovo tvrdenie, že pojem práv nie je na ochranu určitých hodnôt potrebný, by Rothbard bezpochyby reagoval tvrdením, že v slobodnej spoločnosti žiadna iná ochrana ako ochrana individuálnych práv neexistuje. Rothbard je anarchokapitalista a v jeho systéme je dovolené všetko, čo neporušuje princíp neagresie voči osobám, teda všetko, čo neporušuje nárokovatel'né majetkové práva osôb. Rothbard by teda, prirodzene, Singerovu odpoved' neprijal. Rozdiel medzi oboma autormi je tak vlastne aj $\mathrm{v}$ tomto ohl'ade paradigmatický a pramení z rozdielov medzi základnými východiskami ich teórií ako takých.

S tvrdením, že živočíšny boj je prirodzený, ktoré predstavuje Rothbardov tretí argument, Singer v istom zmysle akiste súhlasí. Tvrdí však, že konzumácia mäsa, respektíve chov a zabíjanie zvierat na priemyselné účely nie sú v záujme prežitia človeka nevyhnutne potrebné, ba naopak, škodia zdraviu i životnému prostrediu (2008, 81 - 82). Prikláňa sa dokonca k záveru, že ak je to možné, mali by sme sa usilovat' redukovat' nadbytočné utrpenie i v samej prírode. ${ }^{6}$

V súvislosti s príkladom „Mart’anov-upírov“ platí na Rothbardovo stanovisko Singerova námietka z druhizmu - teda zo vzt’ahovania ochrany len na príslušníkov vlastného živočíšneho druhu. Tu sa však Singerova koncepcia dostáva do trochu

\footnotetext{
${ }^{5} \mathrm{~K}$ pojmu objektívneho a subjektívneho práva pozri napríklad Ottová (2006, 53 - 56).

${ }^{6} \mathrm{~K}$ tomu pozri napríklad jeho prednášku z roku 2016 The Suffering of Wild Animals: Should we do anything about it, and if so, what? [online]. Dostupné na: https://www.youtube.com/ watch?v=1 VYYHLH990A (Navštívené: 16. 6. 2020).
} 
zvláštnej pozície, pretože, keby „Martania-upíri“ prežívali pri naplnení svojich potrieb väčšiu slast', respektíve v prípade strádania väčšiu bolest' ako l'udstvo, v duchu danej koncepcie by sa l'udstvo malo obetovat' a vydat' sa im napospas. ${ }^{7}$

Pokial' ide o Rothbardov argument z potenciálu detí stat' sa dospelými l'ud'mi, Singer tento argument (ako známy zástanca interrupcií a infanticídy), samozrejme neakceptuje a trvá na potrebe zotriet' hranice medzi druhmi na základe spomínaných utilitaristických kritérí.

\subsection{Francioneho chápanie práv zvierat}

Iný prístup $\mathrm{k}$ danej problematike zastáva azda najnekompromisnejší abolicionista súčasnosti, rigorózny zástanca myšlienky práv zvierat Gary L. Francione. ${ }^{8}$ Francione podobne ako Singer tvrdí, že schopnost' cítit' bolest', respektíve trpiet' (angl. sentience), je klúčovým morálnym kritériom. Na rozdiel od Singera však na tejto schopnosti nebuduje konzekvencialistickú, ale deontologickú teóriu (teóriu individuálnych práv). Oproti Rothbardovi je presvedčený, že sama schopnost' trpiet' postačuje na priznanie práv zvieratám, na ich označenie za subjekt, a nie objekt morálnych a právnych vzt'ahov. Francione spája pojmy sentiece a self-awareness a argumentuje, že schopnost' trpiet' je neoddelitel'ná od schopnosti sebauvedomenia, pretože trpiaci tvor si je nevyhnutne vedomý, že je to on, kto trpí.

$\mathrm{S}$ myšlienkou, že v prípade priznania práv zvieratám narazíme na nejasnú hranicu, ktoré živočíchy nimi disponujú a ktoré nie, Francione v zásade súhlasí (pripúšt’a napríklad, že aj hmyz môže potenciálne trpiet', no danú otázku zatial' ponecháva otvorenú skúmaniu). ${ }^{9}$ Argumentuje však, že táto skutočnost' nijako neospravedlňuje aktuálnu prax využívania zvierat $\mathrm{v}$ potravinárskom, odevnom či farmaceutickom priemysle, kde dochádza najmä k využívaniu stavovcov, ktoré jednoznačne bolest' cítia (Francione 2012).

Pojem práv chápe Francione inak ako Rothbard. Tvrdí, že „právo je jednoducho spôsobom ochrany záujmu“"(Francione 2007). Podotýka, že takáto ochrana môže byt' konzekvencialistická alebo nekonzekvencialistická. Prvá je typická pre utilitaristov, akým je napríklad Singer, druhá pre abolicionistov, respektíve pre ustálené chápanie l'udských práv, ktoré sú jednotlivcovi garantované bez ohl'adu na celkové dôsledky

\footnotetext{
${ }^{7}$ Otázkou práv mimozemšt’anov sa Singer zaoberá, hoci opatrne, napríklad v článku Do Aliens Have Inaleinable Rights? [online].

${ }^{8}$ Medzi jeho najvýznamnejšie diela patria napríklad knihy: Animals, Property and the Law (1995), Introduction to Animal Rights: Your Child or the Dog? (2000), Animal Rights: The Abolitionists Approach (2011).

${ }^{9}$ Francione v zásade spĺn̆a Rothbardovo prirovnanie k Schweitzerovi, ktorý sa snažil „nestúpit’ na švába“. Francione sám uvádza, že jeho snahou je vyhýbat' sa vedomému usmrcovaniu hmyzu (Francione 2012).
} 
tejto garancie $\mathrm{v}$ jednotlivom prípade (napríklad slobodu slova má aj ten, s kým nikto nesúhlasí, právo na život má človek bez ohl’adu na to, či je zdravý alebo duševne postihnutý a či jeho smrt' zachráni ostatných a pod.). Kl'účovým a najfundamentálnejším právom, ktoré človek má, je podl'a Francioneho právo nebyt' redukovaným na predmet. Pokial' jedinou morálne relevantnou charakteristikou subjektu je schopnost' trpiet', potom treba toto právo rozš́írit' aj na zvieratá ${ }^{10}$ (tamtiež).

Prirodzenost' živočíšneho boja Francione uznáva, no podobne ako Singer argumentuje, že na rozdiel od mäsožravých zvierat človek nutne nepotrebuje jest' mäso. Poukazuje aj na skutočnost', že zvieratá robia mnoho iných vecí, ktoré my l'udia robit' odmietame a označujeme ich za nemorálne (napríklad psy sa pária na verejnosti, močia na budovy a pod.). Znamená to, že morálnost' l'udského konania nemožno zdôvodňovat' prirodzenost'ou porovnatel'ného konania v prírode (Francione 2000).

\section{Diskusia}

Singerova etická teória síce môže viest' k obetovaniu l'udstva v prospech „vyššej formy bytia“ a ako taká pre nás znie neintuitívne, avšak Rothbard svojimi tvrdeniami o „Martanoch-upíroch“ zasa podkopáva vlastnú argumentáciu o prirodzenom živočíšnom boji. Uvádza, že je objektívne v poriadku, ked' vlk zožerie ovcu a človek akékol'vek zviera, pretože je to prirodzené. Prečo však potom nie je objektívne v poriadku, ked” „Mart'an-upír“ vysaje krv človeka? Alebo to je v poriadku, akurát človek ako racionálny subjekt, ktorý tiež disponuje prirodzenými právami, musí mat' možnost' aspoň sa bránit'? Takúto, respektíve podobnú odpoved' by zrejme dal Francione, ktorý tvrdí, že sebaobrana je jediným legitímnym dôvodom ublíženia zvieratám či iným cítiacim bytostiam zo strany človeka (Abbate 2015, 106).

$\mathrm{V}$ anarchokapitalizme je prípustné všetko, čo nepredstavuje porušenie princípu neagresie. Je zaujímavé, že Rothbard explicitne uvádza, že „Mart’ania“, ktorí by sali našu krv, by v skutočnosti neboli agresormi. Tvrdí, že by sme „nemohli uvažovat', že majú nárok na l’udské práva [...] nie preto, že by boli hriešnymi agresormi, ale kvôli potrebám a požiadavkám plynúcim z ich prirodzenosti, ktoré by boli nevyhnutne v rozpore s našimi““ $(2009,206)$.

Tento výrok môžeme čítat' dvojako:

Ak ho čítame subjektivisticky, tak v ňom Rothbard rezignuje na objektívne platné riešenie danej dilemy a pozerá sa na ňu výlučne z hl'adiska záujmov l'udstva. Takéto chápanie by však bolo v rozpore s Rothbardovým kritickým prístupom k etickému subjektivizmu, ktorý vyjadruje na inom mieste toho istého diela (2009, 57 a 257).

${ }^{10}$ Rothbardov argument det'mi ako „budúcimi dospelými“ je z tohto hl'adiska tiež irelevantný, ked’že zviera rovnako ako diet’a cíti bolest', respektíve dokáže trpiet'. Obaja sú teda subjektmi. 
Ak ho čítame objektivisticky, tak je Rothbardova teória akousi teóriou skupinového egoizmu, ktorá hovorí, že každá skupina racionálnych bytostí má v prípade neodvratnej kolízie s prirodzenými záujmami inej takejto skupiny objektívne platné morálne právo bojovat' o ich naplnenie. Použitie boja „Martanov-upírov“ proti nám by teda $\mathrm{z}$ tohto pohl'adu bolo akýmsi legitímnym prostriedkom sebazáchovy (a ako také by, povedzme, nepredstavovalo porušenie princípu neagresie).

Takéto chápanie je však problematické, pretože je v rozpore s opakovaným dôrazom Rothbarda (i jeho pokračovatel'ov) na tézu, že nikto nesmie - ani v existenčnej núdzi -bez dovolenia siahnut' na vlastníctvo druhého, inak sa dopustí porušenia princípu neagresie (2009, 148 a n.). Rothbard v tom istom diele hovorí napríklad o absolútnom práve majitel'a záchranného člna rozhodnút', komu (a či vôbec niekomu) doň umožní nastúpit' $(2009,199)$. V čom je teda rozdiel medzi človekom-stroskotancom na mori, ktorý zápasí o prežitie, no v duchu rothbardovského libertarianizmu nesmie vliezt' do člna inej osoby bez jej súhlasu (ak to urobí, smie byt' z člna vyhodený do mora, kde sa po čase utopí), a „Mart’anom-upírom“, ktorý sa (či už vlastnou vinou alebo nie) ocitol na planéte Zem, kde zápasí o prežitie s človekom, ktorého krv potrebuje? Pripomínam, že Rothbard po vzore Locka pracuje s pojmom vlastníctva svojej osoby, čo znamená, že zásah do telesnej integrity iného je zásahom do jeho súkromného vlastníctva.

Interpretovat' Rothbardov poukaz na potreby a požiadavky plynúce z prirodzenosti „Martanov-upirov“, tak, že „Mart’ania-upíri“ potrebujú našu krv esenciálne (teda každý deň), zatial' čo stroskotanec sa na mori ocitne len akcidentálne (jednorazovo), neuspokojí. Prečo by malo záležat' na tom, ako často sa záujmy nejakej racionálnej bytosti dostávajú do konfliktu so záujmami inej racionálnej bytosti? Treba si všimnút' i paradox vyplývajúci zo skutočnosti, že konanie „Mart’anov-upírov“, ktoré by nevyhnutne šlo na náš úkor, by z tohto uhla pohl'adu bolo legitímne, zatial' čo vlezenie stroskotanca do člna bez súhlasu jeho majitel'a, ktorému by teoreticky nemuselo nijako škodit', by bolo nelegitímne.

Uspokojivá nebude ani odpoved', že Rothbard a jeho nasledovníci hovoria o takýchto situáciách (napríklad o práve vlastníka člnu nezachránit' stroskotanca na mori, o práve rodičov nestarat' sa o svoje deti a pod.) v kontexte odmietania pozitívnych práv, respektíve pozitívnych povinností, pričom situácia kolízie záujmov l'udí a mimozemšt’anov sa netýka problému pozitívnych práv a povinností, ale legitimity vzájomného boja v unikátnej situácii kolízie. Tu sa totiž možno spýtat', či sú obe práva, ktoré v takomto prípade kolidujú, absolútnymi právami. Kladná odpoved' sa javí logicky problematická: Ako môžu absolútne práva kolidovat? Ak však povieme, že len jedno z práv je absolútne, tak to, ktoré absolútnym nie je, musí absolútnemu právu 
ustúpit', a to na základe príkazov rozumu. Racionálni aktéri by teda nemali dospiet' $\mathrm{k}$ žiadnemu boju a jeden $\mathrm{z}$ nich by sa mal druhému vzdat'.

Nevystačíme si ani s odpoved'ou, že boj sám je objektívne spravodlivým riešením kolízie týchto dvoch práv. Vieme si predsa predstavit', že stroskotanec na mori bude tiež bojovat' o svojvol'ne odopreté miesto v relatívne prázdnom člne, ktorý mu nepatrí, no podla rothbardiánov bude jeho boj nelegitímny (poruší princíp neagresie).

Možno sa tiež pýtat', či je pomyslené právo „Mart'anov-upírov“ na našu krv (voči ktorému máme ,protiprávo“ sebaobrany) negatívnym alebo pozitívnym právom. Ak anarchokapitalista pripustí, že dané právo je pozitívnym právom, tak, samozrejme, protirečí Rothbardovej téze, že v anarchokapitalizme existujú len negatívne práva. Ak bude trvat' na tom, že dané právo je negatívnym právom, tak sa treba spýtat', na základe čoho to tvrdí. Jedinou odpoved’ou, ktorú môže ponúknut', je už spomínaný poukaz Rothbarda na potreby a požiadavky plynúce z prirodzenosti , Mart’anov-upírov“. Takáto odpoved' však jednak zaváňa naturalistickým omylom (vyvodzovaním noriem z faktov), a jednak nás hlavne opätovne vracia k otázke, aký je rozdiel medzi existenčnou potrebou mimozemšt’ana po l'udskej krvi a existenčnou potrebou stroskotanca dostat' sa do člna, ktorá pramení zo skutočnosti, že človek je suchozemský tvor (čiže vychádza tiež z jeho prirodzenosti).

Zdá sa, že tieto otázky nemožno uspokojivo zodpovedat'. Žiada sa preto skonštatovat', že konanie mimozemšt’anov voči nám by jednoducho bolo agresívne. Ak teda Rothbard skutočne tvrdí, že „Mart'ania-upíri“ by neboli agresormi (a implicitne snád” pokladá ich konanie za obdobné sebaobrane), ${ }^{11}$ robí svoju teóriu nekonzistentnou, a to z vyššie popísaných dôvodov.

Je však možné, že Rothbardovo vyjadrenie, že „Mart’ania-upíri“ by neboli hriešnymi agresormi, nemáme čítat' doslovne, ale dôraz máme položit' na slovo „hriešnymi“, nie na slovo ,agresormi“; teda že ide o akési nadnesené, emocionálne, vyjadrenie. Rothbard by z hl'adiska takejto interpretácie implicitne uznával, že mimozemšt’ania sa v skutočnosti dopúšt’ajú porušenia princípu neagresie, a preto je ich konanie objektívne nelegitímne. V danej kapitole však zároveň tvrdí, že živočíšny boj je prirodzený, čím sa vraciame $\mathrm{k}$ otázke, prečo by vôbec malo byt' konanie „Mart'anovupírov“ voči nám nelegitímne. Bud’ teda v takomto prípade neplatí princíp neagresie, alebo nemožno preceňovat' myšlienku prirodzeného živočíšneho boja. Navyše pokial' ide o vzt'ah človeka k zvieratám, v rámci ktorého Rothbard všetko vyššie uvedené rozoberá, je vhodné zopakovat', ako správne poukazujú Singer, Francione a mnohí d’alší, že človek pre svoj život nevyhnutne nepotrebuje jest' mäso.

${ }^{11} \mathrm{~K}$ problému sebaobrany pozri Rothbard (2009, 125 a n.). 
Rothbard by mohol na práve uvedenú námietku odpovedat' zrejme len tak, že on apel na prirodzený živočíšny boj (argument č. 3) pokojne obetuje, že si vystačí s ideou práv viažucich sa k osobám (argument č. 2) a že pokial' ide o otázku nutnosti či nenutnosti jest' mäso, tá nie je podstatná; podstatné je, čomu možno a čomu nemožno v slobodnej spoločnosti legitímne bránit' a odpoved’ou je, že možno bránit' len takému konaniu, ktoré zasahuje do súkromného vlastníctva inej osoby, pričom zvieratá osobami zjavne nie sú. Treba uznat', že takýmito odpoved'ami by Rothbard konzistentnost' svojej teórie v zásade obhájil. Otázkou však ostáva, či je jeho teória uspokojivá.

Ako som už uviedol, rozdiel medzi Rothbardom a Francionem tkvie v odlišnom narábaní s pojmom práv. Zatial' čo Rothbard vychádza z teórie vôle, Francione vychádza z teórie záujmov. ${ }^{12}$ Pre Rothbarda práva predstavujú to, čoho sa možno domáhat', pre Francioneho to, čo zlepšuje postavenie ich nositel'a. S tým sa spája i rozdiel v chápaní subjektu práv. Zatial' čo pre Francioneho postačuje ako definičný znak subjektu schopnost' trpiet', Rothbard požaduje aj d’alšie vlastnosti, akými sú racionalita, schopnost' kooperácie atd'. ${ }^{13}$ Dôležitú rolu tu napokon hrá aj koncept vlastníctva (pre Rothbarda je subjekt vždy vlastníkom), ktoré Rothbard po vzore Locka definuje ako zmiešanie vlastnej práce s vecou nikoho a ktoré je základom všetkých ostatných práv. Pri takejto definícii môžu byt' teoreticky vlastníkmi aj zvieratá - napríklad včely môžu vlastnit' med, ktorý vyrobili, veveričky lieskovce, ktoré nazbierali, kravy trávu, ktorú odhryzli a podobne, avšak absentuje im schopnost' vstupovat' do výmenných vzt'ahov, ktorá je pri definovaní subjektu-vlastníka pre libertariánov klúčová.

Skutočnost', že Rothbard, ktorý kladie radikálny dôraz na vlastníctvo, nemôže pri vymedzení pojmu práva pracovat' s teóriou záujmov, je pomerne zrejmá. Ak by sme totiž za jediný podstatný znak subjektu-vlastníka pokladali schopnost' zmiešat' vlastnú prácu s vecou nikoho, respektíve ideu sebavlastnenia ako takú, a ignorovali by sme požiadavku schopnosti vstupovat' do výmenných vzt'ahov, tak by nám neostávalo iné ako vychádzat' z teórie záujmov a priznat' práva i zvieratám (ked’že každý vlastník má práva). Narazili by sme však na Rothbardom spomínaný problém vztahu vlka a ovce.

${ }^{12} \mathrm{~K}$ filozofickým koncepciám pojmu (l’udských) práv pozri napríklad Pavlovičová (2015).

13 Tvrdenie, že racionalita nositel'a je podmienkou morálnych záväzkov voči nemu, ktoré zastával aj Kant, sa v knihe The Case for Animal Rights snaží svojou filozofickou argumentáciou vyvrátit’ aj Tom Regan (Regan 2004, 176 a n.). Kant hovoril len o takzvaných „,nepriamych morálnych záväzkoch“ voči zvieratám spočívajúcich v téze, že krutost' voči zvieratám je zlá preto, lebo zvyčajne sa premietne aj do krutosti voči l'ud’om. Myšlienku nepriamych záväzkov voči zvieratám zastávajú aj (niektorí) kontraktualisti. Ich postoj podrobuje kritike napríklad Rozemberg, ktorý tvrdí, že skutočnost', že nejaká bytost' sa nachádza mimo zmluvného rámca, neznamená, že sa voči nej zmluvné strany môžu z morálneho hl'adiska správat' akokol'vek: „Ak sú racionalita, schopnost' brat' na seba záväzky a pod. morálne relevantnými vlastnost’ami preto, lebo sa na tom dohodli členovia morálneho spoločenstva, snaha nárokovat' si absolútnu moc nad tými, ktorí doň nepatria, je prejavom extrateritoriality,“ uzatvára $(2013,340)$. 
Došlo by ku konfliktu medzi prirodzenost'ou živočíšneho boja (existenčnou nevyhnutnost’ou mäsožravých zvierat zmocnit' sa iných zvierat) a samým princípom neagresie. Ukázal som, že ak Rothbard chce svoju koncepciu uhájit’ ako zmysluplnú , potrebuje sa vzdat' poukazu na prirodzenost' živočíšneho boja ako argumentu v prospech konzumácie mäsa l'ud'mi. Pokial' Francione nechce upadnút' do podobných problémov (ked' pripustí legitimitu živočíšneho boja medzi zvieratami, ktorým však zároveň chce priznat' práva), musí s ohl'adom na svoju koncepciu práv odmietnut' zasa prioritu idey súkromného vlastníctva, respektíve sebavlastnenia. Či a v akom zmysle to robí, mi nie je celkom jasné. ${ }^{14}$ Problém však v každom prípade ostáva v tom, že pri uznaní legitimity živočíšneho boja sa vlastná hodnota (dôstojnost') subjektu stáva druhotnou v momente, ked' jeden subjekt potrebuje skonzumovat' druhého v záujme prežitia (napríklad lev gazelu). Ako v takomto prípade riešit' vzt'ahy medzi l’ud'mi (napríklad kanibalizmus v čase hladomoru)?

Otázkou je, či teória záujmov nutne vedie $\mathrm{k}$ francionovskému chápaniu práv zvierat. Ak áno, otázka vol'by medzi Rothbardovým a Francioneho prístupom sa rysuje ako otázka základnej paradigmy. Ak nie, tak prinajmenšom sama skutočnost', že máme viac než jednu možnost', ako vymedzit' pojem práv, povedzme, aspoň čiastočne oslabuje presvedčivost' Rothbardovej teórie.

Otázkou tiež je, či je vôbec pojem práv pre ochranu zvierat objektívne potrebný. Ako sme videli, Singer argumentuje, že nie je.

Prirodzene, porovnávat' anarchokapitalizmus Murraya Rothbarda a utilitarizmus Petra Singera možno len na sociálno-etickej úrovni (pretože anarchokapitalizmus, na rozdiel od utilitarizmu, nie je zároveň individuálno-etickou teóriou). Nazdávam sa však, že otázky sociálnej etiky sa nedajú skúmat' v absolútnej izolácii od otázok individuálnej etiky. V danom ohl'ade za zmienku stojí, že ani v tábore pravicového libertarianizmu nenachádzame jednotný postoj $\mathrm{k}$ problematike práv zvierat. Zdá sa, že s Rothbardom nesúhlasil napríklad Robert Nozick, ktorý uvádza, že „dodatočné prínosy, ktoré Američania dnes z pojedania zvierat získavajú, ho neospravedlňujú. Takže by sme ich jest' nemali“ (2015, 53). Z citátu síce nie je celkom zrejmé, či sa Nozick vyjadruje (len) na individuálno-etickej, alebo (aj) na sociálno-etickej úrovni, kontext však nasvedčuje skôr tomu druhému. ${ }^{15}$ Nasledovníci Ayn Randovej (tzv. objektivisti) sa zasa hlásia k Rothbardovmu pohl'adu na práva zvierat, no na rozdiel od neho nevolajú po zrušení štátu. Yaron Brook, významný súčasný predstavitel’ objektivizmu, na otázku, či by mali existovat’ zákony proti týraniu zvierat, výslovne odpovedá záporne.

\footnotetext{
${ }^{14}$ Niektorí totiž kritizujú jeho majetkovo-právnu rétoriku (pozri napríklad: https://www.youtube. com/watch?v=QeP0g0c2sHE; Navštívené: 3. 9. 2020).

${ }^{15}$ Napríklad aj Josh Milburn argumentuje, že Nozick je výrazne naklonenejší myšlienke práv zvierat ako vel’a iných libertariánov (Milburn 2017).
} 
Tvrdí, že zákon má chránit' výlučne práva l'udí. Ked’že zvieratá nemôžu byt' nositel’mi práv (založených na teórii vôle), nemožno týranie nikomu nepatriacich či vlastných zvierat zákonne zakazovat', hoci je takéto konanie, ako Brook sám uvádza, nemorálne (na individuálno-etickej úrovni). ${ }^{16}$ Teda zatial' čo človek disponuje (absolútnym) právom nebyt' mučený, zviera možno beztrestne týrat'. Podl'a Brooka to síce na úrovni osobnej etiky (osobnej zodpovednosti jednotlivca pred vlastným svedomím i objektívnym poriadkom sveta) nie je morálne, $\mathrm{z}$ hl'adiska spravodlivého usporiadania spoločnosti však nemožno nikoho nútit', aby tak nekonal.

Keby Rothbard nesúhlasil s Brookovým tvrdením, že týranie zvierat je na individuálno-etickej úrovni nemorálne, mal by prapodivnú definíciu morálneho dobra, respektíve by bol zrejme morálnym nihilistom, čo však on očividne nie je. Podl'a všetkého by teda súhlasil, že týranie zvierat je na individuálno-etickej úrovni objektívne nemorálne, dokonca, že je príkro nemorálne. Znamenalo by to, že podl'a neho je nemorálne bránit' komukol'vek v páchaní príkrej nemorálnosti.

Rothbardova teória prirodzeného zákona sa usiluje o objektívne spravodlivé usporiadanie spoločenských vzt'ahov. Idey objektívneho morálneho dobra a zla teda predpokladá (ked’že spravodlivost' je morálnou kategóriou), pričom v otázke ochrany objektívnych morálnych hodnôt ako takej je, ako sme videli, minimalistická. Určite treba súhlasit's tvrdením, že pozitívny zákon sa nemá snažit' postihovat' všetko objektívne nemorálne konanie (nech už takéto konanie vymedzíme prakticky akokol'vek). V prípade dokonale slobodnej spoločnosti možno to isté povedat' o prirodzenoprávnych normách, ktorými sa l’udia spravujú vo vzájomných vzt’ahoch v pomyselnom bezštátnom stave (ktorého dosiahnutie je Rothbardovým ciel'om). Avšak tvrdenie, že pozitívne zákony štátu, respektíve nepísané prirodzeno-právne pravidlá pomyselného slobodného spoločenstva (ktoré sú vlastne morálnymi normami), musia tolerovat' nejakú objektívnu radikálnu nemorálnost' (respektíve že nesmú bránit' jej páchaniu), a to takú, ktorej zavrhnutiahodnú povahu si uvedomujú nielen všetci ostatní, ale aj sám páchatel' (ktorý napríklad práve st’ahuje zaživa mačku z kože či sústavne drží svoje prasa v klietke s rozmermi jeho tela), znie paradoxne a núti nás byt' voči danej koncepcii značne podozrievavými.

Z libertariánskeho hl'adiska, pravdaže, nemožno legitímne zasahovat' do súkromia jednotlivcov, hoci by v ňom páchali objektívne nemorálnosti, pokial' neporušujú princíp neagresie (Rothbard sa napríklad zasadzuje za slobodu pornografie či prostitúcie: 2009, 319). K podobnému záveru prichádzajú aj mnohí utilitaristi, no s tým rozdielom, že skôr ako o princípe neagresie hovoria o princípe škody. Rozdiel medzi prin-

${ }^{16}$ Brook, Y.: Yaron Answers: Should There Be Laws Against Animal Cruelty? [online]. Dostupné na: https://www.youtube.com/watch?v=AbD3s-jPspE (Navštívené: 3. 9. 2020). 
cípom neagresie a princípom škody možno vidiet' $v$ tom, že prvý uvedený princíp vychádza z libertariánskeho pojmu vlastníctva (a ako taký sa vzt'ahuje len na osoby), zatial' čo druhý vychádza z pojmu bolesti. Porušenie princípu neagresie teda bude tkviet' v neoprávnenom zasahovaní do súkromného vlastníctva iného, porušenie princípu škody bude založené na neoprávnenom spôsobení fyzickej alebo duševnej bolesti inému. V anarchokapitalizme je povinnost’ou každého zdržat' sa zásahov do súkromného vlastníctva druhého a uznat' právo jednotlivca na sebaobranu v prípade takýchto zásahov. V utilitarizme je osobnou zodpovednost’ou každého jednotlivca i zodpovednost'ou spoločenstva minimalizovat' bolest'.

Ked' však anarchokapitalista uzná, že týrané zviera prežíva podobné utrpenie ako týraný človek, môže túto skutočnost' zodpovedne ignorovat? Pokial' Rothbard súhlasí, že týranie zvierat je morálne zvrátené na individuálno-etickej úrovni, ako môže nedbat' na túto skutočnost' na sociálno-etickej úrovni a neuznat' právo iných zasiahnut' v prospech týchto bytostí? ${ }^{17}$ Odpoved' na položenú otázku je (žial') relatívne jednoduchá: Rothbard to robí na základe logiky lockovskej teórie prirodzeného zákona a súkromného vlastníctva, ktorú dovádza do krajných dôsledkov.

\section{Záver}

Čo možno z vyššie uvedeného vyvodit? Napríklad to, že anarchokapitalizmus je redukcionistická teória. Usiluje sa zúžit' kritériá (spoločensky) akceptovatel'ného konania na jediné - na ochranu lockovsky chápaného súkromného vlastníctva. A možno práve $\mathrm{v}$ tom je jeho problém. ${ }^{18}$ Utilitarizmus, ktorý zužuje morálne kritériá na potešenie alebo bolest', je každopádne tiež redukcionistický. ${ }^{19}$ Samozrejme, že prípadný pluralistický prístup akúkol'vek etickú teóriu komplikuje. Možno však poukázat' napríklad na príspevok Johna M. Finnisa, ktorý predostiera vlastnú koncepciu prirodzeného zákona (vychádzajúcu z diela Tomáša Akvinského), ktorá sa snaží riešit práve (aj) problém redukcionizmu (Finnis, 2019). Netvrdím, že ide o tú správnu teóriu. Finnisov pokus nám však prinajmenšom ukazuje, že neredukcionistické úvahy sú hodné námahy a pozornosti. ${ }^{20}$ Zaujímavé je, že aj Nozick akoby vo vyššie citovanom výroku počítal s viac než len jedným morálnym kritériom. V súvislosti so zabíjaním zvierat

\footnotetext{
${ }^{17}$ S tým sa tiež spája otázka, ako vnímat’ týranie postihnutých l’udí, ktorí nemajú a nikdy ani nebudú mat' mentálne schopnosti zdravého človeka.

${ }^{18}$ Niektorí poukazujú aj na nedostatky v súvislosti so samým pojmom vlastníctva v libertariánskom myslení (Hudecová 2011, Fábry 2013).

${ }^{19} \mathrm{Ku}$ kritike utilitaristického redukcionizmu pozri napríklad Finnis (2011, 160 - 163); v inštitucionálnom kontexte pozri napríklad Holländer (2009, 17 a n.).

${ }^{20}$ Otázke práv zvierat sa Finnis bližšie venuje na s. 300 - 301. Zvieratá nepokladá za subjekt práv, pretože nie sú schopné participovat' na (všetkých) neredukovatel’ných základných dobrách, ktoré v svojom diele vymedzuje.
} 
hovorí o malých prínosoch, ktoré l'udia získavajú z konzumácie mäsa. Hoci nie je utilitarista, ale libertarián vychádzajúci z Locka, hovorí vlastne o určitom kalkule úžitku. Popri kritériu vlastníctva ${ }^{21}$ je teda preňho nejakým spôsobom relevantné i toto kritérium. Za pozornost' stojí, že i sám Locke v svojom etickom myslení pracuje nielen s pojmom prirodzeného zákona, ale aj s pojmami potešenia a bolesti (vd’aka čomu ho dokonca niektorí označujú za proto-utilitaristu). ${ }^{22}$ Mnohí odborníci na Locka si dnes lámu hlavu nad tým, ako zmierit' tieto dva momenty v jeho myslení (Sheridan, 2016). Nie je to zrejme možné, kým budeme uvažovat' redukcionisticky.

$\mathrm{Na}$ otázku, ako konkrétne to spravit' neredukcionisticky, $\mathrm{v}$ tomto príspevku odpoved' neprinášam, no nazdávam sa, že ani nutne nepotrebujem. Zastávam názor, že na zaujatie (odmietavého) postoja $\mathrm{k}$ Rothbardovmu nazeraniu na práva zvierat (respektíve na právnu ochranu zvierat), ${ }^{23} \mathrm{v}$ konečnom dôsledku postačuje poukaz na zásadnú problematickost' predpokladu, že skutočnost', ked' jednotlivec alebo spoločnost' bránia inému jednotlivcovi v týraní zvierat, je objektívne morálne horšia ako dané týranie. A práve tento problematický predpoklad musí prijat' každý, kto s Rothbardovým chápaním súhlasí. ${ }^{24}$

\section{Literatúra}

ABBATE, C. E. (2015): The Search for Liability in the Defensive Killing of Nonhuman Animals. Social Theory and Practice, 41(1), 106 - 130.

BROOK, Y.: Yaron Answers: Should There Be Laws Against Animal Cruelty? [online]. Dostupné na: https://www.youtube.com/watch?v=AbD3s-jPspE (Navštívené: 22. 4. 2020).

FÁBRY, B. (2013): Niektoré nedostatky pojmu vlastníctvo v liberálnom myslení. [online] Pro justice. Dostupné na: https://www.projustice.sk/teoria-prava/niektore-nedostatky-pojmu-vlastnictvo-vliberalnom-mysleni (Navštívené: 20. 5. 2020).

FINNIS, J. M. (2019): Prirodzený zákon a prirodzené práva. Bratislava: Kalligram.

FRANCIONE, G. L. (2000): Questions and Answers on Introduction to Animal Rights: Your Child or the Dog? [online]. Dostupné na: https://www.abolitionistapproach.com/media/pdf/ abolitionist-online-2000.pdf(Navštívené 29. 7. 2020).

\footnotetext{
${ }^{21}$ Vlastníctvo však Nozick nechápe rovnako ako Locke a Rothbard.

${ }^{22} \mathrm{~K}$ tomu pozri napríklad Heidt $(2014,19$ a n).

${ }^{23}$ Nemusí totiž íst' o koncept práv, na ktorý apeluje Francione, ale skôr o určitú ochranu zvierat pred utrpením. Domnievam sa, že netreba radikálne tvrdit', že l'udia a zvieratá sú si svojou hodnotou rovní a že preto je nemorálne použit' zviera napríklad na medicínsky výskum, ktorý môže zachránit' život človeku (čiže tvrdit', že zviera má právo na život, respektíve právo nebyt' inštrumentalizovaným, rovnako ako človek).

${ }^{24}$ Rothbardovu pozíciu teda pokladám za neakceptovatelnú a prikláňam sa k Singerovej téze, že pojem práv nie je pre ochranu zvierat nevyhnutne potrebný. Na druhej strane sa však nedokážem stotožnit' ani so Singerovým utilitarizmom, z ktorého vyplýva, že v niektorých situáciách je správne zachránit' zviera na úkor človeka (napríklad topiaceho sa dospelého koňa namiesto postihnutého novorodenca), teda so systémom, ktorý stiera hranice medzi druhmi tak, že opúšt’a ideu l'udskej dôstojnosti. To je už však téma na samostatnú, nel’ahkú prácu.
} 
FRANCIONE, G. L. (2007): Clarifying the Meaning of „,Right“. [online]. Dostupné na: https://www. abolitionistapproach.com/clarifying-the-meaning-of-right/ (Navštívené: 28. 7. 2020).

FRANCIONE, G. L. (2012): Sentience. [online]. Dostupné na: https://www.abolitionistapproach. com/ sentience/ (Navštívené: 29. 7. 2020).

HEIDT, C. (2014): Utilitarianism Before Bentham. In: Eggleston, B., Miller, D. E. (eds.): The Cambridge Companion to Utilitarianism. Cambridge: Cambridge University Press, 16 - 37.

HOLLÄNDER, P. (2009): Filipika proti redukcionizmu. Bratislava: Kalligram.

HUDECOVÁ, A. (2011): Libertariánsky pohl'ad na vlastníctvo l'udského tela. Filozofia, 66 (5), 491 - 496

JEMELKA, P. (2014): Etická a axiologická reflexe života zvírat a se zviŕaty (Několik poznámek k tématu). Filozofia, 69 (6), $482-492$.

MILBURN, J. (2017): Robert Nozick on Nonhuman Animals: Rights, Value and the Meaning of Life. Woodhall, A., DA Trinidade, G. G. (eds.) Ethical and Political Approaches to Nonhuman Animal Issues. Londýn: Palgrave Macmillan, 97 - 120.

NOZICK, R. (2015): Anarchie, stát a utopie. Praha: Academia.

OTTOVÁ, E. (2006): Teória práva. 2. vyd. Šamorín: Heuréka.

PAVLOVIČOVÁ, Z. (2015): Ambivalentnost' l'udských práv a neurčitost' ich pojmu z pohl'adu filozofie. Filozofia, 70 (9), $759-769$.

REGAN, T. (2004): The Case for Animal Rights. Berkeley: University of California

ROTHBARD, M. N. (2009): Etika Svobody. Praha: Liberální institut.

ROZEMBERG, A. (2013): Astronautka Astrid a jej úbohá mačka (Niekol'ko poznámok k teórii nepriamych záväzkov voči zvieratám). Filozofia, 68 (4), 332 - 342.

SHERIDAN, P. (2016): Locke's Moral Philosophy. Stanford Ensyclopedia of Philosophy. [online]. Dostupné na: https://plato.stanford.edu/entries/locke-moral/ (Navštívené13. 5. 2020).

SINGER, P. (2017): Do Aliens Have Inaleinable Rights? [online]. Dostupné na: http://nautil.us/issue/47/consciousness/do-aliens-have-inalienable-rights (Navštívené: 21. 4. 2020).

SINGER, P. (2008): Spisy o etickom žití. Bratislava: Vydavatel'stvo Spolku slovenských spisovatel'ov, 2008.

SINGER, P. (2016): The Suffering of Wild Animals: Should we do anything about it, and if so, what? [online]. Dostupné na: https://www.youtube.com/watch?v=1VYYHLH990A (Navštívené: 16. 6. 2020).

Martin Turčan

Právnická fakulta UK v Bratislave

Katedra teórie práva a sociálnych vied

Šafárikovo námestie 6

P. O. BOX 313

81000 Bratislava

e-mail: martin.turcan@flaw.uniba.sk

ORCID ID: https://orcid.org/0000-0002-4616-6730 